\title{
PAPERMAKING FROM SELECTED MALAYSIAN FIBERS: AN INVESTIGATION OF ITS ARTISTIC POTENTIAL THROUGH THE CREATION OF ORIGINAL PAPER ARTWORKS
}

\section{Chen Teng Beng}

As I reflected upon and tried to interpret what has transpired in my past, my experience with handmade paper in later years became more and more meaningful to me. My first contact with handmade rice paper was before I went to elementary school, when my generous grandpa allowed me a sheet to paint on. In the late 1940's I was treated by a Chinese "Sin-Seh" for a disease called "Chua". Literally translated the word means a snake. His herbal medicine was comprised of greenish grass paste macerated by a means of a granite pestle and mortar - the greenish grass paste reminded me of the crude fabricated mass of fiber which is precisely what papermaking is all about.

My first encounter with Western handmade paper was in the early 1950 's when I utilized it as a supportive substrate for water color painting. This was Barcham Handmade water color paper manufactured in England. My first work sold was a water color painted on this paper when I was in sixth grade.

Finally, I made my first paper in 1967 in Cranbrook Academy of Art as a Fulbright-Hays recipient. This handmade paper was actually made from my shredded white cotton shirt hydrated in the Hollander beater. The first papermaker I heard about was Douglas Morse Howell whom I had the good fortune of meeting in his long Island studio in May 1972, on my way back to my native land. Returning to Malaysia in the late Spring 1972 to establish a fine arts division in the School of Humanities, Science University of Malaysia, Penang, 1 began in earnest to experiment with the native plants. I discarded the idea of utilizing cotton rags and substituted the western technology with that of the indigenous technology, that is, the use of granite mortar and the granite pestle to macerate or pound the plant fibers into pulp. This idea I borrowed from the Chinese 'Sin Seh' who treated me for 'C hua'.

The search for materials a new sources of raw material for papermaking has been an on-going process ever since the $C$ hinese first made paper in the early Han Dynasty (1 st Century B.C.). Two hundred years later (105 A.D.) Tsai Lun, an enunch and manager of household utensils in the imperial court of Emperor Ho, experimented with a myriad of materials for papermaking. Likewise Dr. Jacob Christian Schaeffer (1718-1790) did a pioneering job in attempting to utilize plant fibers as a new source for paper. Others include Pierre Leorier de Lisel and Guettard.

These predecessors could not possibly have exhausted all the species of plants mother nature has provided us; for whatever reasons they are created, it is up to the ingenuity of man to explore their potentials for the benefit of mankind -- be it herbal medicine or papermaking. The search for plant fibers 
as a new source of raw materials for the production of paper continues with the contemporary papermaker and the papermaking artist.

Thus the first component of this research focuses on selected Malaysian plants, viz: "Pandan", banana, and pineapple, to see whether these plant fibers are suitable for handmade paper and paper artwork. Why, then, are these plants chosen for this study?

Banana and pineapple are major argricultural crops in Malaysia. Yet after the crops are harvested, they presently serve no further use. This is in contrast to other agricultural wastes, such as rice straw, which is fully exploited by Indonesians to make shampoo, to cultivate mushrooms, as fertilizers, and also as a natural color-agent in batik-making industry.

By and large Malaysia is basically an agriculturally-based economy even though it is undergoing rapid modernization process. Thus, ways and means should be found to convert whatever its agricultural residues might be, into a profitable source of raw material for whatever utilization - papermaking, fertilizer, and the like. Currently no one, other than myself, is utilizing indigenous plants for papermaking in Malaysia. Even the identified literary sources fail to investigate these selected plants.

Cellulose $\left(\mathrm{C}_{6} \mathrm{H}_{10} 0_{5}\right)$ is the carbohydrate from which all paper is made (Louis Stevenson, 1940, p. 16). All plant fibers contain 70-76\% cellulose (Mar Carter, 1971, p. 29). Some contain more than others. For instance, cotton has a very high percentage of cellulose. Hence, it is easier to pulp. Thus, the cellulose contained in banana, pineapple and "pandan" plants has to be isolated from other non-cellulose substances such as lignin, wax, pith, etc. before it is suitable for papermaking. The isolation, or fiber separation, is carried out by means of chemical, mechanical or hand-beating processes.

In this study the required isolation of the aforementioned fibers will be accomplished by handpounding, using the pestle and the mortar (both wooden and granite). Thus, the research questions are: What kind of fibers will result from this method of isolation? Are the fibers difficult to isolate by means of the indigenous technology? Are they suitable for hand papermaking and paper art? What kind of a sheet formation will result from these fibers?

The second aspect of the study will deal with how these processed fibers can be interpreted as fibrous material and as an artistic medium. Regarding methodology, "In forming a paper in a hand-mould, the worker has only his sense of weight and balance to guide him, and the thickness of each individual sheet of paper depends entirely upon the skill of the Craftsman." (Dard Hunter, 1943, p. 457). Like any artistic process, papermaking has its own prescribed and enshrined canons to observe; but sometimes the artist intentionally defies them. What will be the reaction to his or her defiance vis-a-vis the status quo of current art forms? Will his or her defiance be read as an aesthetic backlash to an alleged dehumanizing technological world?

Contradictory theories regarding sheet formation do arise. Papermakers differ from each other and yet the resultant is a sheet of paper. It has been claimed that papers are superior to those made on the paper machine, even when the machine is furnished with the same grade of pulp. This is due to the

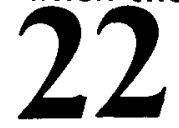


four-way shake that the handmade paper receives, as compared with the twoway shake given to the machine made paper". (Newell Stephenson, 1953, p. 647). But Henderson Clapperton and William Henderson assert, "The shake given by the vatman is in two directions, so that there is very little in the tensile strength in the length and breadth of the sheet." (1947, p. 286). The antithesis of right and wrong in the two aforementioned statements remain a research question. I have also observed that a sheet is formed simply by dipping the deckle and the mold in the vat of slurry without any shake applied. Does this mean that paper formed in this mode of operation is inferior?

Besides its technical significance, paper should also possess some expressive or innate qualities. "The color, surface, thickness, and "feel" of papers evoke subtle association responses that can increase or diminish the total expressiveness of a lithographic print." (Garo Antreasian and Clinton Adams, 1971, p. 330). In fact I would expand the checklist to include texture, lustre, transparency or translucency. The research will examine if the banana, pineapple and 'pandan' fibers possess the above mentioned qualities. Fiber is an important component of paper art. It is the physical material which will form the physical ontological basis of a work of art. Roman Ingarden states: "The material world enters as a background and displays itself in the shape of the ontological foundation of the work of art." (1975, p. 260). Other than approaching papermaking in a conventional mode solely, I will also elicit some of my original techniques that have not been propounded by any other papermaking artists. To translate these techniques, I will also originate some tools. Eugene Kaelin posits, "The history of the development of modern art in many art media indicates that the search is still going on." (1970, p. 87).

The third aspect of the study will deal with the aesthetic dimension of my paper artwork. The above findings to extend the range of papermaking tradition through creation of original artwork will encompass the data of the discussion in this section. Since it is a new medium and material, the artistic process of papermaking needs an intelligent interpretation to make it comprehensible. Hence, I hope to translate my experience with fibrous material into words and to articulate a series of artistic-technical approaches with the medium. As David W. Ecker has hypothesized, "If it is possible to describe the artistic process as a series of problems and their controlled resolutions, the ensuing generalizations may be of no small consequence to the teaching of art." (1963, p. 284).

The content and sequential treatment of handmade paper as a new medium present fresh aesthetic problems, and new research questions arise: What aesthetic judgments are involved in paper art? To what degree does the fibrous material shape the ontological foundation of paper art? What is paper art? What is paperness in paper art? How is it different from other media? I hope, incidentally, the answers to these questions will enrich our aesthetic experience. As Eugene Kaelin puts it, "Each successful discovery has added to our understanding of the structure of aesthetic objects." (1970, p. 88).

While the emphasis is on my own artistic research, as an art educator 1 believe what $\mathrm{I}$ am doing has social and economic implications. I find formalist Western theories of art and art education in applicable to the third world. An alternative model has to be formulated and the concept of art education needs a broader definition. What conception of art education might emerge from this research? I do not know. That's why I am doing this research. 
Resolution of the above questions may well challenge existing theories. In any event, my descriptive approach should avoid preconceived theories. Thus, phenomenology as a research method has been chosen in order to reflect upon and describe my own experiences as researcher, artist, and art teacher.

\section{REFERENCES}

Antreasian, Garo Z., \& Adams, Clinton. The Tamarind Book of Lithography: Art and Technique. New York: Harry N. Abrams, Inc., 1971.

Carter, Mary E. Essential Fiber Chemistry. New York: Marcel Dekker, Inc., 1971.

Clapperton, Robert Henderson. Modern Papermaking. Oxford: Basil Blackwell, 1947.

Ecker, David W. The Artistic Process of Qualitative Problem Solving. Journal of Aesthetics and Art Criticism, 1963, 21, 283-290.

Hunter, Dard. Papermaking: The History and Technique of an Ancient Craft. Reprint of 1943 edition. New York: Dover Publications, Inc., 1978.

Ingarden, Roman. Phenomenological Aesthetics: An Attempt at Defining its Range. Journal of Aesthetics and Art Criticism, 1975, 33.

Kaelin, Eugene F. Art and Existence. Lewisburg: Bucknell University Press, 1970.

Stephenson, J. Newell. (Ed.). (1953). Manufacture and Testing of Paperand Board (Vol 3). New York: McGraw-Hill Book Company, Inc.

Stevenson, Louis Tillotson. The Backaround and Economics of AmericanPapermaking. New York: Harper and Brothers, Publishers, 1940. 